\title{
Quality of Life and Psychosocial Needs of Children Suffering from Chronic Skin Diseases
}

\author{
Mia Roje, Ines Rezo, Gordana Buljan Flander \\ Child and Youth Protection Center of Zagreb, Zagreb, Croatia
}

\begin{abstract}
Studies show that children suffering from chronic skin diseases have more negative mental health indicators and lower quality of life than general population and than children suffering from other chronic diseases. The aim of this study was to gain a detailed insight into how the children suffering from chronic skin diseases experience the quality of various aspects of their life - their self-image, experience of disease, social relationships and actual needs, with the purpose of improving the quality of their life. In-depth interviews were conducted with eleven children $(6 \mathrm{~m}, 5 \mathrm{f})$, treated at the Skin Disease Clinic Srebrnjak, aged 10 to 15 and suffering from visible skin symptoms for longer than two years. The analysis of answers indicates that children report a disturbed self-image, lower self-satisfaction and higher physical self-perception. They attribute negative characteristics to themselves, have unpleasant emotions and expect negative outcomes in the future. Some children have experienced serious peer-bullying, some have pleasant social experiences, but all of them reported feelings of shame and fear from the environment reactions to their skin. Needs they express are related to acceptance, education of the environment, instrumental and emotional support. The findings of this study clearly indicate that mental health professionals should be included in the care of children with chronic skin diseases.
\end{abstract}

Key words: psychodermatology, children, quality of life, needs

Copyright @ 2015 KBCSM, Zagreb

e-mail: alcoholism.kbcsm@gmail.com•www.http//hrcak.srce.hr/acoholism

\section{Introduction}

The inner world of an individual and his/ her relationship with the environment are expressed at the 'boundary', the biggest organ of our body - the skin [1]. The skin and psyche are most often linked in the studies in-

Correspondence to: Mia Roje, mag.psych. 00385977693266

mia.roje@poliklinika-djeca.hr cluding the following groups of disorders [2]: (1) psychophysiological dermatoses - primarily psychiatric diseases resulting in skin disorders and (2) secondary psychological disorders occuring as reactions to the visibility and the chronic course of skin diseases. According to Hong, Koo and Koo [3] skin diseases are mostly not life threatening, which is the reason why they receive less attention both medically and psychologically. However, individuals suffering from skin diseases, also suffer psychosocially, equally or even more than 
those with other chronic somatic diseases [4], especially children and youth [5].

Children suffering from chronic skin diseases show more signs of depression and anxiety [6-8], a poorer self-image [9], and they estimate their quality of life lower than children with other diseases like cystic fibrosis, asthma, epilepsy and enuresis [6]. Studies show that among skin diseases, atopic dermatitis is most strongly related with negative indicators of mental health in children $[7,10,11]$, which is explained multifactorially. Atopic dermatitis is a condition which is: (1) visible, (2) incurable in most cases, (3) causes sleeping problems, (4) causes constant itching, (5) can cause reactions of disgust from the environment $[7,8,12]$.

The psychological indicator most often studied in children with chronic skin diseases is the quality of life. According to the World Health Organization, the quality of life is defined as individuals' perception of their position in life in the context of the culture and value systems in which they live and in relation to their goals, expectations, standards and concerns (The WHOQOL Group, 1995). It includes several aspects - physical health, the psychological status, the level of independence, social relationships, personal beliefs and their relationship to the salient features of their environment [13]. The quality of life of children suffering from skin diseases is most often examined by quantitative methodology, questionnaires, predominantly CQOL (Child Health-Related Quality of Life) [14], CDQOL (Children's Dermatology Life Quality Index) [15] and CLQU (Children's Life Quality Index) [16]. Measures CQUL and CDQOL are based on the quality of life linked with physical health, while CLQU measures various aspects of children's lives. Both questionnaire structures contain certain bias. Children with lower life satisfaction due to their health condition will not differentiate in the first two questionnaires because the questions only refer to health. On the other hand, according to the CLQU factors [16], a child may be satisfied with family circumstances, the economic status, his/her academic achievement, $\mathrm{s} /$ he can positively perceive his/her future, and at the same time be dissatisfied with e.g. his/her health, appearance and social status due to a skin condition. Regardless of how intensely dissatisfied a child may be with his/ her aspects of life affected by a skin condition, his/her total life satisfaction will seem at least average because of the satisfaction with other aspects of life. Therefore, the results obtained by questionnaires need to be critically interpreted and complemented by qualitative methodology.

In most studies of the quality of life of children suffering from skin diseases, at least a part of questionnaires was filled in by adults in their environment. Davies, Noll, DeStefano, Bukowski and Kulkarni [17] emphasize that adult perceptions can be significantly different from child perceptions. For example, unclear link between the severity of skin disease symptoms and the quality of life of children can be explained by physicians assessing the severity of symptoms, while in some cases parents assess the quality of their children's lives $[18,19]$. When children are not directly asked about their experience, which is not rare in medical studies, the understanding of various concepts is incomplete [20]. Qualitative research with children suffering from skin diseases are rather scarce, and they can potentially provide a detailed insight into children's experience and perceptions. Williams, Gannon and Soon [21] studied the quality of life of middle school children suffering from bullous epidermolysis. Results 
show that their quality of life was mostly deteriorated by itching, pain, difficulties in joining activities with other children, visibility of their symptoms and a feeling of being different. Presented results cannot be obtained by usual measurement questionnaires. That is the reason why it is important that studies of this population are approached by qualitative methodology, i.e. clinically.

The aim of this research was an in-depth study into the experience of the quality of various aspects of life of children suffering from chronic skin diseases. Consequently, the following research problems were established:

- To examine how children suffering from chronic skin diseases experience themselves;

- To examine how these children experience of their social relationships, behaviors of other people towards themselves towards their disease;

- To examine what children suffering from chronic skin diseases need to improve their experience of the quality of life.

\section{Methodology}

\section{Subjects}

Criteria in selecting research subjects were: (1) age 10-15, (2) the presence of visible skin symptoms, (3) the presence of visible skin symptoms for at least two years. The minimum age of children was defined based on developmental maturity for introspection necessary to answer the study questions. Maximum age was defined in order to maintain relative age-homogenous sample. The presence of visible skin symptoms for several years was set as a criterion in order to avoid answers during adaptation and to include relatively developed self-perception, social perception and experientially built psychosocial needs.

Subjects in this study were children aged 10 to $15(\mathrm{D}=13)$ who had been examined or hospitalized at the Skin Disease Clinic Srebrnjak. All children and parents who were asked to participate in the study gave their consent. Nine out of eleven children ( 6 boys and 5 girls) had had visible skin symptoms from early childhood, while two had had visible skin symptoms for a few years. Eight children had atopic dermatitis diagnosed, two children's diagnoses were not yet confirmed, while one child had a rash and facial swelling in contact with allergens.

\section{Materials and methods}

Data were collected by in-depth semistructured interviews during 35 to $70 \mathrm{~min}$ utes $(M=48$ minutes). Parents were presented with the text of informed consent for participation in the study and the purpose of the study and data proceeding were explained if necessary. After parents/carers signed the informed consent form, the child was read and presented with an especially designed informed consent for children participating in the study. The child's signature on the informed consent form signified the beginning of audio recording of the interview. Interviews were conducted on the premises of the Skin Disease Clinic Srebrnjak, with only the child and the interviewer, a psychologist experienced in working with children, present in the room.

\section{Data analysis}

The interview material was then transcribed by an independent researcher. Inter- 
pretative phenomenological analysis of the content (IPA) was applied, using the Atlas.ti research software. Each transcript was read several times. After that answers were summarized and a preliminary interpretation of results was obtained. Then we conducted a categorization of answers and identified the main themes. These themes were divided into meaningful clusters. Original transcripts were consulted during the process, in order to authenticate the foundations of themes and clusters of answers obtained from the participants. Each transcript was coded following defined themes and clusters, with minor changes of the names of themes and the introduction of new themes. Finally, all transcripts were coded again, following the final list of themes and clusters. The credibility of the analysis was ensured by two independent professionals working according to the same principles. Their disagreements were discussed and supervised by an independent researcher specialized in qualitative analyses.

\section{Results}

The presentation of results related to the experience of various aspects of lives of children suffering from chronic skin diseases are organized according to main problems.

\section{Experience of themselves}

Experience of themselves in children suffering from chronic skin diseases highlights three main themes: (1) their experience of themselves through their skin disease, (2) disturbed image of their physical self, (3) reduced satisfaction with themselves on the whole.

Seven children described themselves mentioning their skin disease, prior to giving basic data about themselves, like age or school grade. Describing themselves, all participants mentioned some signs of their skin disease, like sores, rash or shingles, although they were not asked about these.

\section{"T have those sores which leak water." $(f, 12)$}

All girls and four out of six boys described dissatisfaction with their physical appearance. Their dissatisfaction ranged from moderate to strong and it affected their functioning.

"I am not really satisfied because I have this on my arms (showing), but then I tell myself, I can put on something with long sleeves, I have beautiful eyes."

$$
(m, 10)
$$

"I sometimes feel so ugly when everything is stuck. together, I am like a monster. I don't want anybody to see me and I don't want to go out." $(f, 12)$

Participants mostly described generalized dissatisfaction with themselves, although in one girl and in two boys that dissatisfaction was related only to their physical aspect.

"I don't know how I could be satisfied when this when it permeates every part of me, I mean my

$$
\text { life." (f, 15) }
$$

"I don't know what I'd change on myself... Well, almost everything (...) It has to do with this on my skin, but I'd change everything (...). I don't know what exactly. Everything." (f, 10)

"I'd be more satisfied if I recovered, all that would look more beautiful." (m, 13)

\section{Experience of skin disease}

Children suffering from chronic skin diseases linked their disease to: (1) undesirable characteristics, (2) negative life outcomes and (3) unpleasant emotions. All children said that their physicians told them that they would probably recover till the end of their puberty, which has significantly shaped their experience of disease. 
Among the undesirable characteristics which children related to their disease, oversensitivity, weakness and feelings of helplessness were the most pronounced, especially in acute phases. Children said that then they felt dependent on their parents and their help, which additionally intensified their perceived weakness and helplessness.

'I can't manage any of these things on my own (...) The moment I wake up, I have to take a photo of my skin, and then my Mum tells me what to do, or comes home from work (...) Then I weep all the time, I feel too weak and I weep." (f, 10)

Eight participants linked their disease to some negative outcomes in life or perceived that some opportunities other children had, were denied to them (both professionally and socially).

'I don't think. I'll be a football player, I think I could have been if this wasn't present. I can play anything, but I won't be a real football player". (m,

10)

'T'd like to go to the beach with my friends. There'll be a high school graduation trip. I'd like to go everywhere, but I think I can't (...) Then I won't have these friends". (f, 10)

On the other hand, self-confidence and trusting their life opportunities despite skin disease, was notified in two participants.

"But I am a gymnast. Only, our club does not offer good conditions (...) It has nothing to do with my

skin, why shouldn't I be a gymnast?" (f, 12)

"I give my maximum and I put maximum trust in myself”. (m, 13)

Emotions children associate with their disease were most often fear, sadness and disgust. All these emotions were present in eight of the participants.
"The worst thing is that I don't know what I'm scratching during the night, I wake up with blood under my nails, I'm afraid of sleeping". (f, 13)

"I may have that my whole life and it makes me sad (weeping)". (f, 13)

"It's disgusting, I felt like throwing up". (m, 10)

All participants said they were told that disease remission was expected before the end of their puberty. Children perceived this in two significantly different ways. Seven participants found hope and optimism in this information, while four of them suspected that physicians and parents were unjustifiably trying to comfort them, which caused their distrust and helplessness.

"At the end of my puberty, when I am nineteentwenty, it will be over (...) When I think of it, I feel better". (m, 10)

"I've been told so many times that this or that would belp me, and then it never helps in the long run (...) I don't know if I recover and I'm afraid that I'll be like this forever (...) Well, I don't believe what they say". $(f, 13)$

\section{Experience of social relationships}

The experience of social relationships in children suffering from chronic skin diseases reveals three main themes: (1) a feeling that they are different, (2) loneliness and a lack of understanding of the community and (3) fear and shame of others' reactions. Some participants reported serious difficulties in social interactions, like bullying.

Children reported their feeling that they were different. They noticed that and they thought their environment noticed that, too.

'I know I'm different, I know I'm not allowed to eat what others eat, I'm not allowed to go where they 
go, and such (...) Then, of course, they notice, they ask, and I have to talk about that again". (m, 13)

Children who did not know other children with chronic diseases reported a strong feeling of loneliness and others' inability to understand them. Four participants had other children with chronic diseases (skin, or other organs) in their nearby surrounding and despite their loneliness they related to 'at least someone' who understood how they felt.

"There's nobody else and they don't understand how it is (...) They don't even believe before they see it, my coach thought I was exaggerating". $(f, 15)$

"For example, they say that I should stop scratching, as if it's just like that. Somebody who's never itched so much can't understand how it feels (...) I feel lonely, no matter how others relate to me (...) I don't blame them, I know they can't understand".

$$
(f, 13)
$$

'T'm not happy my sisters have this disease too. But then we understand each other better and they know how it is and that it's not infectious (...) Yes, then it's easier because, at least, I have somebody". (f, 10)

Emotions described by the participants, which occurred in social relationships, were most often shame and fear from others' reactions. They described the feeling that everybody was looking at them due to their visible skin symptoms. Despite positive and supporting response from the environment described by eight of the participants, shame and fear still occurred especially when they were meeting new people or were in a new environment.

'If somebody's looking at it, I cover it because I'm

$$
\text { ashamed". (m, 15) }
$$

"Now, if I had so many crusts, I'd not wear shorts (...) So they wouldn't say I was 'crusty' (...) I'd be scared of that'. (m, 10)
"When those symptoms occur, I always think somebody's constantly staring at me, or something like that (...) I shut down exactly because of that". (m, 13)

'I can't say they told me something bad, they only stare and ask many questions, but then I don't know how someone may respond and how I'd respond if they told me something (...) Now those who know me perhaps won't say anything, but there are many people I don't know yet". (f, 13)

Four participants described peer bullying they had experienced due to their skin condition. It was emotional abuse - insulting and ostracizing. Their emotional reactions were sadness, fear, shame, anger and withdrawal.

'I was full of sores on my lower leg muscles and then they told me: "Cover yourself, look at yourself, you're like a mister crusty or mister cucumber". It burts me a little (...) I feel sad, it a sort of hurts

$$
\text { me". (m, 10) }
$$

"Always when they see it, they first step back (...) I feel weird (...) It's sad, because they think it's infectious and they step back." (f, 10)

"Then the boys from my class say, like what is it, how can you have it, and I say, it's how I am and I can't change (weeping) (...) I thought they were just curious, but they intentionally asked me a bundred times and then I knew they were taunting me (...) I step away, feeling ashamed". (f, 13)

"They ask: "Do you inject yourself?" or "What are you diggin' there?" and so (...) once every day. They hurt me about that (...) I just simply step away or go out (...) I feel annoyed, but I don't fight, I'm a good boy".

\section{Children's needs}

The main needs of children suffering from chronic skin diseases are: (1) understanding, (2) help with specific tasks, (3) psy- 
choeducation of the society and (4) psychological support.

Participants said that they needed understanding from their environment in several areas: itching and pain, feeling of irritation, procedures they had to undergo (putting on ointments, taking medicines), missing classes and extracurricular activities and they needed as 'normal life' as possible.

"Sure I know I should not scratch myself and if they tell me not to do that, they only remind me to scratch and they irritate me (...) Then they don't understand why I'm irritated". (f, 13)

'If I say I can't come to sports training, it means I really can't because I love that more than anything in the world. I don't want to explain every time that my face is like a balloon". (f, 15)

"I don't want to talk about it every day. I take a pill if I need it, and that's it. Without somebody watching the pills all the time and thinking that I can't play something due to my allergy". (m, 10)

All the participants described their parents' support as something important, related to instrumental support like reminding them to take their therapy, put on ointment, bandage, excusing their missed classes, explaining medical terminology and similar. Only two participants said they had someone to talk to about their fears and concerns related to their disease.

"Everybody's good, everybody, they give me pills, my

Mum brings those pills and creams". (m, 13)

'When it's tough, I tell my Mum and it's easier then (...) Well, because she gives me a pill”. (m, 10)

The participants reported that it was easier for them when they were occupied with some fun activities, because then their focus was not on their symptoms. They experience the re-focusing of others' behavior as a form of support and help in dealing with difficulties.

"Then we play something or do something and I

$$
\text { forget it itches". (f, 10) }
$$

"It is much better when my sister or mum engage me in some fun game, than when they just say I should not scratch myself. Like I forget and it is less pain-

$$
\text { ful'. (m, 10) }
$$

One of the main difficulties the participants encountered was a lack of knowledge about their disease in their surroundings, i.e. the others' perception that they were infectious. All participants said that they would like others to know that they were not infectious and that they could freely mingle with others.

"I think that they step back because they are afraid

I might infect them. I explain I'm not infectious

(...) I'd like the people to know that". $(f, 10)$

"They should know that I'm as normal as anybody, that I'm not a monster". ( $m, 13)$

Only two of the participants had ever talked with a psychologist, but none of them talked in the context of their disease. At the beginning, four participants spontaneously expressed a need to talk about their feelings and problems, and at the end all participants said that it was nice/comfortable, that they felt relieved, although it was a research interview.

"I feel better because I somehow said it all, tanght you some things and because you were interested in all that (...) because you said you liked the time you spent with me". (m, 13)

"I liked it (...) I'd talk with you again". (f, 10)

A need to ventilate was noticed in eight participants. They showed a need to talk at length, in detail and explicitly about their symptoms and medical procedures, although 
they were not asked about that. They expressed various comparisons and fantasies related to their disease, which they did not have an opportunity to tell others.

"It was at night, I was sleeping with my mum and it started itching and then burning. I went to the toilette, looked in the mirror (...) From my neck down I saw blood, something like drops. Then I tore everything down from myself, as much as I could (authors note: bandages and adhesive plaster) because it is very painful and itchy (...) They injected me here, here, here, here (shows his arms). Twenty here and fourteen here (...) With a needle. It's worst when they prick in the vein, here where my bone is. Exactly on the bone, and it hurt a lot. I cried. Very much. I cried because it burned as if someone took a piece of coal and stabbed it into my wound. In fact coal from hell because it is hot (...) When they inject me, there's some cream or something slimy in that syringe, and then it's like a worm wiggling and creeping under my skin". (m, 10)

\section{Discussion}

In this study we examined the experience of various quality aspects of the life of children suffering from chronic skin diseases. The first research problem was examining how children suffering from chronic skin diseases experienced themselves, i.e. their selfimage. Self-image or totality of oneself and self-esteem [22] of our participants is undermined. Primarily, they have a deteriorated image of their physical self, which they clearly link to their skin symptoms. It is understandable that at the pre-adolescent and adolescent age it is very important to fit in and look beautiful according to the proclaimed standards of beauty [21,23-25].
However, a self-image is a multidimensional construct, and apart from the physical aspect, it also includes the intellect, emotions, philosophical insights, social relationships and communication [26]. We could notice that in most participants the self-image was generally deteriorated, regardless of the fact that the physical self was only one part of it. This can be explained with the constant presence and visibility of skin symptoms, which are the main prerequisites for some aspect of the self-image to prevail in the experience of one's overall self [27]. Individuals at this developmental age, who are visibly different in some aspects, are at risk of developing a poor self-image, and especially a low satisfaction with themselves [28]. For pre-adolescents and adolescents, physical appearance is strongly related to their overall self-image [23], which has also been supported by our results showing that negative physical self dominates the overal self-image.

Furthermore, we examined the experience of the skin condition in children suffering from chronic skin diseases. Our results show that the participants link their disease to undesirable or embarrassing aspects of themselves (characteristics and emotions) and that they expect negative outcomes in the future. The participants reported helplessness, weakness and over sensitivity as their characteristics, which is consistent with the results of previous studies. Research show that chronically ill children often experience themselves as sensitive and dependent and that they have a perception of a lack of control [2931]. Such experience of oneself is realistic in certain circumstances. It is expected that children in acute phases of their disease are more sensitive and dependent on the support of their environment. However, in our practical work, it is important to distinguish such 
situations from constant characteristics and support children's independence in periods when it is possible and in aspects which they can deal with. That facilitates the fulfillment of their developmental tasks and their natural need to build their own identity [32]. Their predominant emotions are fear, sadness and disgust, which is related to their negative selfimage, especially in relation to their physical self. Previous studies found that the predominant emotion children link to their skin diseases is disgust [21], but all these emotions are very unpleasant for children. In practice, it would be useful to process these unpleasant emotions with children and provide treatment aiming at helping them to develop coping mechanisms and emotionally accept themselves and their disease.

Results show that children suffering from chronic skin conditions can perceive that they are deprived of some opportunities, and they experience it as something which negatively impacts on their future. Such findings were not present in previous studies of children suffering from skin conditions; however they were present in children suffering from other chronic diseases, e.g. diabetes [33]. Children suffering from chronic skin diseases have at least as disturbed self-image and negative indicators of mental health as children suffering from other chronic diseases [2,7-9]. Therefore, it is expected that, having their health condition in mind, they have a similar view to their future. We found expressed faith in themselves and in a positive future in two participants. Additional research is needed into the potential protective factors in children with such perception, in order to help chronically ill children develop their coping mechanisms.

A perspective of the future of children suffering from chronic skin diseases offered to these children is that they will probably recover till the end of their puberty. Our participants understood that in two basically different, i.e. opposite ways. Some of our participants gained hope from this perspective and it enabled them to see their future in a more positive light. Studies show that giving some meaning and time limits to difficulties, makes it easier for the people to cope with them, mostly because it encourages a feeling of control and predictability [34,35]. On the other hand, some participants found the perspective of recovery at the end of their puberty insincere and patronizing, which deteriorated their trust in physicians and parents. This finding shows that it is of crucial importance to talk to children about their understanding of information and comforting offered to them, and that sincerity (within the limits of the appropriateness of information) is important for the relationship with the child as a patient.

The third research problem was to examine the experience of children suffering from chronic skin diseases regarding their social relationships, and how others related to them and their disease. Results indicate that children feel different and thus lonely in the society. In their pre-adolescent and adolescent age, it is important to identify with their peers and feel part of the group $[24,36,37]$. In this developmental period, a strong need for social comparison is also present [38] and it is expected that the participants compare themselves with their peers and acutely perceive if they are different. If children or adolescents feel considerably different due to some characteristics which are important to them, it is somewhat difficult for them to achieve and maintain membership in their peer groups [28]. Consistent with that, our results indicate that relationships with other children suffer- 
ing from chronic diseases offered our participants a space to make friends who understood them which alleviated their subjective experience of loneliness.

Regardless of the fact that the majority of the participants had mostly pleasant experiences in social interactions, they reported their constantly present feeling of shame and fear of others' reactions. This finding can also be explained with their developmental phase. Pre-adolescents and adolescents experience a feeling that they are constantly in the spotlight, overestimating the level of others' looking at them and analysing them [38]. Although it is possible that those around them notice their skin condition, there is a certain possibility that the participants overestimated the level of others' attention. It is also important to take into account the deteriorated selfimage the participants reported. It is possible that they project their own negative perception of themselves to those in their environment, expecting that others see them in as a negative perspective as they see themselves, which functions as a self-fulfilling prophecy [39].

A very important finding of this study is the experienced peer-bullying related to skin conditions. Offending and ostracizing are equally important and serious forms of abuse, as is physical abuse, although the former are often perceived as less dangerous [40]. The victims of peer-bullying are often different from others due to some visible mark. They require some kind of special care and protection [41], which puts the children suffering from skin diseases at risk for peerbullying. That risk is especially present in transitions, i.e. when children change school or move into some other area. As our results show, teasing and ostracizing usually occur in a new environment. Previous studies also show that transitions into a new environment increase the frequency of questioning and intrusive comments [24]. Abusive behaviour can cause various consequences, like: loneliness, depression, sadness, fear, insecurity, low self-esteem, even diseases, which can emerge immediately or in later life [40]. Before everything, it is important to focus special attention on children suffering from chronic skin diseases as potential victims of bullying and work on the prevention of abusive behaviours.

In order to address our final research problem, we examined the needs of children suffering from chronic skin diseases to improve their experience of the quality of life. Children expressed a need for others' understanding for their subjective experience, objective limitations and obligations related to their condition and a need to feel as normal members of the society as possible. Understanding is a key factor in case of any stressful or traumatic experience. It is how the surrounding can support a person [42, 43]. Although in the available literature we do not find studies about this aspect of children suffering from skin conditions, our results show that chronically ill children and youth need to belong to the society as anybody else [44]. It is also important to perceive their identity separate from their chronic disease, so that it can develop in a healthy way [30]. Instead of receiving understanding from their environment, children often experience ignorance and concern related to their disease. They perceive that their peers are often afraid of infection and repeatedly ask questions about their skin. Knowledge can significantly reduce concerns and limit the number of questions asked by their peers. Education of their wider environment is important so that chil- 
dren suffering from chronic skin conditions are understood and accepted.

Children express a need for support about practical tasks, like reminding them to take their therapy, put on ointments and similar, and all the participants in our study expressed satisfaction with their family's instrumental support. Especially younger children, who still do not have their abstract thinking developed enough, who do not clearly connect causes and consequences and have difficulties with anticipating long-term consequences [45], cannot cope with the responsibility for their medical care. Parents should be additionally instructed about the importance of taking on certain responsibilities in caring for their children and introduced to developmentally appropriate transfer of responsibility onto their children when they are ready. It is also important to note that, related to their health condition, only two children reported emotional support provided in their family. Emotional support, like talking about the child's problems and feelings is often equally important as instrumental support [21] and it is important to teach children's families about that.

Although the participants express that they need and want to talk about their feelings, they generally do not have an opportunity for professional support. That a mental health professional is needed can be heard directly from these children and recognized in the feedback about their feelings of relief after they have talked with our researchers, although it was a study interview. Their need is obvious from what they tell and from their extensive venting about their difficult experience although they were not directly questioned about these. Children suffering from chronic skin diseases would benefit from therapy groups and support groups guid- ed by mental health professionals, based on children's expressed need to belong to their group and receive understanding from children with similar experience. Due to objectively deteriorated health status, deteriorated self-image, poor self-esteem, negative perception of social relationships, fear for their life and health, and many developmentally inappropriate concerns which these children reported, experience of these children can be seen as highly stressful and traumatic [46]. Negative views of themselves, their environment and the future, which the participants reported, are a typical example of depressive cognitive distortions $[47,48]$, which is indicative for the child mental status. That is the reason why it is the society's responsibility to provide professional support for these children in order to support their development.

The theoretical value of this paper is in that being the first to examine the experience of children with chronic skin diseases in Croatia, and is among the first to examine their experience and needs in-depth. The practical value of this paper is in concrete answers and guidelines for work with children suffering from chronic skin diseases, which are obtained directly from the affected children. The limitations of this study is the small sample of children suffering from chronic skin diseases, since they are present in the population with up to ten percent, depending on the criteria of categorisation [8]. An important issue here is how representative our participants' answers are for the whole population. The qualitative methodology provided an in-depth insight into the experience of children with chronic skin diseases. Based on these results, designing and conducting quantitative research with more significant statistical strength and a possibility of generalizing the data is necessary in the future. Although 
foreign studies do not find significant differences in children's experience based on actual diagnoses, there are indications that there are differences in the quality of their lives. Most participants in this study suffer from atopic dermatitis, which is important for the interpretation of results. Further research might study and compare children's experience and needs in relation to their specific diagnoses.

The aim of this study was an in-depth examination of the experience of various aspects of life in children suffering from skin diseases - their experience of themselves, their disease, social relationships and needs with the purpose of improving the quality of their lives. Results show that children suffering from skin diseases experience themselves through their physical aspect and that they have a deteriorated self-image, reflecting on reduced self-satisfaction. They associate their skin disease with personal weakness, helplessness, sensitivity and fear, sadness and disgust with their own bodies. Some children perceive that they are deprived of life opportunities and anticipate negative outcomes in the future due to their skin conditions. The prospect of recovering till the end of puberty is comforting for some children, while some of them feel it is not sincere which causes their

\section{References}

1. Koo J, Lebwohl A. Psychodermatology: The Mind and Skin Connection. American family physician 2001;64:1873-1879.

2. Gupta MA, Gupta AK. Psychodermatology: an update. J Am Acad Dermatol 1996;34:1030-46.

3. Hong J, Koo B, Koo J. The psychosocial and occupational impact of chronic skin disease. Dermatologic therapy 2008;21:54-9.

4. Rapp SR, Feldman SR, Exum ML, Fleischer AB, Reboussin DM. Psoriasis causes as much disability resistance. In social situations children suffering from chronic skin diseases feel different, lonely and concerned about others' reactions, while some experience peer bullying due to their disease. Needs children report are mostly related to receiving understanding from the environment, instrumental and emotional support and to psychoeducation of the society. Basic implications ensuing from these results are needs for: (1) systematic inclusion of mental health professionals into the care of children suffering from chronic skin diseases and (2) inter-sectoral co-operation in the protection of children suffering from chronic skin diseases. Mental health professionals can provide individual and group support to these children, and psychoeducation and support for their parents, while co-operation of the education and social welfare systems is necessary to sensitize the society, educate the public and establish a co-operation with schools in the prevention and intervention in cases of peer bullying.

\section{Acknowledgements}

None

\section{Conflict of interest}

None to declare as other major medical diseases. J Am Acad Dermatol. 1999;41:401-7.

5. Senra MS, Wollenberg A. Psychodermatological aspects of atopic dermatitis. Br. J. Dermato. 2014;170:38-43.

6. Gupta MA, Gupta AK. Psychiatric and psychological co-morbidity in patients with dermatologic disorders. Am J Clin Dermatol 2003;4:833-42.

7. Beattie PE, Lewis-Jones MS. An audit of the impact of a consultation with a paediatric dermatology team on quality of life in infants with atopic 
eczema and their families: further validation of the Infants' Dermatitis Quality of Life Index and Dermatitis Family Impact score. Br. J. Dermato 2006;155:1249-55.

8. Blessmann Weber M, Prati C, Soirefman M, Mazzotti NG, Barzenski B, Cestari TF. Improvement of pruritus and quality of life of children with atopic dermatitis and their families after joining support groups. J Eur Acad Dermatol Venereo 2008;22:992-7.

9. Papadopoulos L, Walker C, Aitken D, Bor R. The relationship between body location and psychological morbidity in individuals with acne vulgaris. Psychology, health \& medicine 2000;5:431-8.

10. Lawson V, Lewis-Jones MS, Finlay AY, Reid P, Owens RG. The family impact of childhood atopic dermatitis: the Dermatitis Family Impact Questionnaire. Br. J. Dermato 1998;138:107-13.

11. Lapidus CS. Role of social factors in atopic dermatitis: the US perspective. J Am Acad Dermatol 2001;45:41-3.

12. Balkrishnan R, Housman TS, Carroll C, Feldman $\mathrm{SR}$, Fleischer AB. Disease severity and associated family impact in childhood atopic dermatitis. Arch Dis Child 2003;88:423-7.

13. WHOQOL group. The World Health Organization quality of life assessment (WHOQOL): position paper from the World Health Organization. Social science \& medicine 1995;41:1403-9.

14. Graham P, Stevenson J, Flynn D. A new measure of health-related quality of life for children: preliminary findings. Psychology and Health 1997;12:65565.

15. Lewis-Jones MS, Finlay AY, Dykes PJ. The infants' dermatitis quality of life index. Br. J. Dermato 2001;144:104-10.

16. Lewis-Jones MS. A comparative study of impairment of quality of life in children with skin disease and children with other chronic childhood diseases. Br. J. Dermato 2006;155:145-51.

17. Davies WH, Noll RB, DeStefano L, Bukowski WM, Kulkarni R. Differences in the child-rearing practices of parents of children with cancer and controls: The perspectives of parents and professionals. Journal of Pediatric Psychology. 1991;16:295-306.

18. Rumsey N, Harcourt D. Visible difference amongst children and adolescents: issues and interventions.
Developmental neurorehabilitation. 2007;10:11323.

19. Stalder JF, Bernier C, Ball A, De Raeve L, Gieler U, Deleuran M, Marcoux D, Eichenfield LF, Lio P, Lewis-Jones S, Gelmetti C. Therapeutic patient education in atopic dermatitis: worldwide experiences. Pediatric dermatology. 2013;30:329-34.

20. Woodgate R. Part I: An introduction to conducting qualitative research in children with cancer. Journal of Pediatric Oncology Nursing 2000;17:192-206.

21. Williams F, Gannon K, Soon K. The experiences of young people with epidermolysis bullosa simplex: A qualitative study. Journal of health psychology 2011;16:701-10.

22. Majdak M, Kamenov Ž. Stigmatization and picture of self in juvenile perpetrators of criminal acts. Kriminologija i socijalna integracija 2009;17:41-53.

23. Taub DE, Greer KR. Physical activity as a normalizing experience for school-age children with physical disabilities implications for legitimation of social identity and enhancement of social ties. Journal of Sport \& Social Issues 2000;24:395-414.

24. Titman P. The impact of skin disease on children and their families. in Walker C (ed.) Psychodermatology: The Psychological Impact of Skin Disorders. Cambridge: Cambridge University press, 2005.

25. Seidah A, Bouffard T. Being proud of oneself as a person or being proud of one's psysical apearance: What matters for feeling well in adolescence? Social Behavior and Personality: an international journal 2007;35:255-68.

26. King RG. Fundamentals of human communication. New York: MacMillan Publishing Company; 1979.

27. Fox KR, Corbin CB. The physical self-perception profile: Development and preliminary validation. Journal of sport and Exercise Psychology 1989;11:408-30.

28. Hagell A, Coleman J, Brooks F. Key data on adolescence. London: Association for Young People's Health; 2013.

29. Eiser C, Morse R. A review of measures of quality of life for children with chronic illness. Archives of disease in childhood 2001;84:205-11.

30. Juul J. Obitelji s tinejdžerima. Zagreb: Pelago; 2006.

Alcoholism and Psychiatry Research 2016;52:133-148 
31. Hysing M, Elgen I, Gillberg C, Lie SA, Lundervold AJ. Chronic physical illness and mental health in children. Results from a large-scale population study. Journal of Child Psychology and Psychiatry 2007;48:785-92.

32. Erikson EH. Identity and the life cycle. New York: W.W. Norton \& Company; 1994.

33. Streisand R, Swift E, Wickmark T, Chen R, Holmes CS. Pediatric parenting stress among parents of children with type 1 diabetes: the role of self-efficacy, responsibility, and fear. Journal of Pediatric Psychology. 2005;30:513-21.

34. Hagger MS. Self-regulation: an important construct in health psychology research and practice. Health Psychology Review 2010;4:57-65.

35. Vohs KD, Baumeister RF, editors. Handbook of self-regulation: Research, theory, and applications. NewYork: Guilford Press; 2011.

36. Catalano RF, Oesterle S, Fleming CB, Hawkins JD. The importance of bonding to school for healthy development: Findings from the Social Development Research Group. Journal of School Health. 2004;74:252-61.

37. Waldrip AM, Malcolm KT, Jensen-Campbell LA. With a little help from your friends: The importance of high-quality friendships on early adolescent adjustment. Social Development 2008;17:832-852.

38. Lerner RM, Steinberg L. Handbook of Adolescent Psychology, Volume 1: Individual Bases of Adolescent Development. New Jersey: John Wiley \& Sons; 2009.
39. Aronson E, Wilson TD, Akert RM. Social psychology. 5th ed. New Jersey: Prentice Hall; 2005.

40. Bilić V, Buljan Flander G, Hrpka H. Nasilje nad djecom i među djecom. Jastrebarsko: Naklada Slap; 2012.

41. Zapf D, Einarsen S. Individual antecedents of bullying: Victims and perpetrators. Bullying and harassment in the workplace: Developments in theory, research, and practice. 2011:177-200.

42. Wilson JP, Thomas RB. Empathy in the treatment of trauma and PTSD. New York: Brunner-Routledge; 2004.

43. Crenshaw DA, Hardy KV. The crucial role of empathy in breaking the silence of traumatized children in play therapy. International Journal of Play Therapy 2007;16:160.

44. Sawyer SM, Drew S, Yeo MS, Britto MT. Adolescents with a chronic condition: challenges living, challenges treating. The Lancet. 2007;369:1481-9.

45. Berk L. Child Development. Boston: Allyn \& Bacon, 2006.

46. Arambašić L. Psihološke krizne intervencije. Zagreb: Društvo za psihološku pomoć; 2000.

47. Buljan Flander G, Tarabić BN, Cuković-Bagić I. Child Abuse and Neglect: Croatian Dental Practitioners' Experience and Knowledge. Alcohol Psychiatry Res 2015;51:127135.

48. Kovacs M, Beck AT. Maladaptive cognitive structures in depression. Am J Psychiat 1978;135:52533.

\section{Kvaliteta života i psihosocijalne potrebe djece koja boluju od kroničnih kožnih oboljenja}

Sažetak - Istraživanja pokazuju da djeca oboljela od kroničnih kožnih bolesti imaju više negativnih indikatora mentalnog zdravlja i nižu kvalitetu života od opće populacije djece, ali i od djece oboljele od brojnih drugih bolesti. Cilj ovog istraživanja bio je dobiti detaljan uvid o doživljaju kvalitete raznih aspekata života djece koja boluju od kroničnih kožnih bolesti - slike o sebi, doživljaju bolesti, socijalnih odnosa te konkretnih potreba u svrhu poboljšanja kvalitete života. Provedeni su dubinski intervjui s jedanaestero djece (6 M, 5 Ž) liječene na Klinici za kožne bolesti Srebrnjak u dobi od 10 do 15 godina, koja više od dvije godine imaju vidljive kožne promjene. Analiza odgovora ukazuje da djeca koja boluju od kroničnih kožnih bolesti izvještavaju o narušenoj slici o sebi, imaju niže zadovoljstvo sobom i doživljavaju se kroz tjelesni aspekt. Vezano uz svoju bolest pripisuju si negativne osobine, doživljavaju neugodne emocije i očekuju razne negativne ishode u budućnosti. Neka djeca 
doživjela su ozbiljno vršnjačko nasilje, neka djeca imaju ugodna socijalna iskustva, no sva su djeca izvijestila o sramu i strahu od reakcija okoline s obzirom na svoju kožu. Potrebe koje izražavaju odnose se na prihvaćanje, edukaciju okoline, instrumentalnu i emocionalnu podršku. Iz nalaza ovog istraživanja proizlazi jasna potreba za uključivanjem stručnjaka mentalnog zdravlja u skrb o djeci s kroničnim kožnim oboljenjima.

Ključne riječi: psihodermatologija, djeca, kvaliteta života, potrebe 
